\title{
Letter from the Editor-in-Chief: The JIBS40/AIB50 Anniversary Issue: Innovations in international business theory
}

\section{Lorraine Eden}

Journal of International Business Studies (2009) 40, I407- |4I0. doi:10.1057/jibs.2009.66

\section{INTRODUCTION}

The Academy of International Business (AIB) is the leading global association of scholars and specialists in the field of international business. Established in 1959, AIB has around 3000 members from over 75 countries involved in the creation and dissemination of knowledge about international business and policy issues. The objectives of AIB, as set forth in its constitution, are to foster education and advance professional standards in the field of international business. The association is designed to transcend the boundaries of single academic disciplines and managerial functions to enhance international business education, research and practice.

The Journal of International Business Studies (JIBS) is the official publication of the Academy of International Business. The journal's goal is to publish insightful, influential and timely articles that make significant contributions to our knowledge of international business studies. The journal's domain encompasses not only the international dimensions of the main business disciplines such as management, marketing and finance, but also the international business dimensions of other social sciences such as economics, political science, psychology and sociology. JIBS is an interdisciplinary journal; its broad scope is designed to create accessible, thought-provoking content that is widely read and cited by the general academic business community. In other words, JIBS is the premier intellectual home for scholars engaged in "conversations" about the international dimensions of business. ${ }^{1}$

The first volume of JIBS, edited by Ernest W. Ogram Jr. with the help of a 10-member Editorial Board and published in 1970, consisted of two issues, 13 articles and 186 pages, with a print run of 300 copies. In 1994, when JIBS was 25 years old and under the direction of Editor Paul W. Beamish with the help of a 45-member Editorial Board, the journal published 23 articles and five notes in four issues, totaling 434 pages, with a print run of 4145 copies. JIBS celebrated its 25th anniversary with "An analysis of twenty-five years of research in the Journal of International Business Studies", written by Andrew C. Inkpen and Paul Beamish and published in JIBS 25.4.

Last year, AIB celebrated its 50th anniversary, and this year JIBS is celebrating its 40th anniversary. To commemorate these two milestones, the JIBS editors decided to publish a Special Issue of the journal, called the "IIBS40/AIB50 Anniversary Issue: Innovations in International Business Theory". The purpose of the Special Issue was 
to publish a set of articles that typified the very best of what the JIBS editorial team would like to see appear regularly in the journal in terms of insightful and influential theory. The Anniversary articles were designed to be the new benchmark against which other articles would be measured - articles that would be very widely read, highly cited, influential and impactful within the international business field.

The editorial team consciously chose not to restrict the subject areas for the Anniversary Issue. Scholars were invited to send their best work, and all topics that fit within the domain of the JIBS Statement of Editorial Policy (see http://www.jibs .net) were considered. The key criteria for manuscript acceptance were innovativeness and potential contribution to international business theory. Manuscripts could also have empirical content as long as they were guided by newly developed theory. The Call for Papers suggested the following examples of suitable topics:

- Building on existing theories from other disciplines (for example, economics, sociology or political science) and reinterpreting them in terms of international business theory.

- Creating new theory about old or new forms of international business (for example, business groups, cross-national networks, e-business, emerging market firms, international entrepreneurship, mergers and acquisitions or offshoring).

- Creating new theory on existing constructs in international business (for example, clustering, corruption, knowledge-seeking FDI, liability of foreignness, institutional or cultural distance, political risk, semi-globalization or tacit knowledge).

- Developing new theory based on existing international business theory (for example, internalization theory, the OLI paradigm or the "stages theory" of internationalization).

- Developing a theoretical paper on innovation or innovations in international business.

- Proposing a new "big idea" for international business theory.

The Call for Papers was published in July 2007, with manuscripts being accepted from that date through mid-March 2008. All submissions went through the regular double-blind review process. All of the JIBS Area Editors and many members of the JIBS Consulting Editors Board were actively involved as Special Issue Editors for the Anniversary Issue. Once an editor recommended acceptance of a manuscript for publication in JIBS, the article then went through a second screening process before it was selected for inclusion in the Anniversary Issue.

In response to the Call for Papers, JIBS received 73 submissions originating from authors at institutions in 20 countries around the world. (Home region of submitting author, by institution, were: Australia 5, Asia 9, Middle East 3, Europe 20 and North America 36.) Of the 73 submissions, 44 articles were selected for external review; these were handled by 20 different Area Editors and Consulting Editors. After several rounds of double-blind review and revisions, six of those articles now appear in this issue. Two articles included in the Anniversary Issue were submitted separately, but were deemed by the editors to be of such quality that they should be included in the Anniversary Issue (Johanson \& Vahlne and the Perspective by Buckley \& Casson). The eight accepted articles were written by 18 authors, nine of whom are currently at institutions in North America, seven in Europe and two in Australia/New Zealand. Lastly, two submissions to the Anniversary Issue have been accepted and two conditionally accepted for publication in regular issues of the journal.

Concluding the articles in the Anniversary Issue is a Perspective written by the JIBS Editor-in-Chief and the authors (or designates) of the 1970-1985 JIBS Decade Awards. These awards, presented at the June 2009 AIB meetings, were given to the most influential articles published during the journal's first 16 years. The authors briefly discuss the core insights of their papers and assess the relevance of their work for today's scholars; a short history of the JIBS Decade Award precedes these mini-retrospectives. The Anniversary Issue ends with a thank you to and list of all the reviewers and Consulting Editors who were involved in this project.

\section{THE JIBS40/AIB50 ANNIVERSARY ARTICLES}

It is particularly fitting that the authors of the most widely cited and perhaps most highly influential JIBS article (Johanson \& Vahlne, 1977) have an article included in the Anniversary Issue. Johanson and Vahlne, in "The Uppsala internationalization process model revisited: From liability of foreignness to liability of outsidership", re-examine and update the Uppsala internationalization process model to take account of changes in theory development, business practices and the global environment over the past 30+ years. The authors argue that the environment for business should now be seen as a network or web of relationships, rather than the economists' neoclassical view of 
markets. A key difference between the old and new models is viewing the firm as an exchange unit rather than a production unit. Outsidership relative to the relevant network, rather than psychic distance, is the root cause of uncertainty and precipitates the internationalization process. The change mechanisms are "essentially unchanged", according to the authors, with the addition of trust building and knowledge creation. The authors conclude that international business scholars should formulate a "more unified explanation of the emergence and growth of the multinational enterprise" by looking for similarities between internalization theory/the OLI paradigm and their networkbased internationalization process model.

Hennart in "Down with MNE-centric theories! Market entry and expansion as the bundling of MNE and local assets" argues that internalization theory (Anderson \& Gatignon, 1986) and internationalization process theory (Johanson \& Vahlne, 1977) are MNE-centric theories where the initial mode of entry and its subsequent evolution are driven by the MNE. Hennart, however, starts "on the other side of the table", with local firms and the transactional characteristics of their complementary assets. He models foreign market entry as the optimal assignment of equity ownership between local asset owners and the MNE. Two key concepts in his analysis are markets and residual rights of control. He argues that the most efficient way to bundle the MNE's firm-specific advantages with the services of complementary assets, when transaction costs are tied to their sale, should be simultaneously determined by the MNE and the local asset owner. The choice between different entry modes then becomes a question of different assignments of residual rights between the MNE and the local resource owner. Hennart argues that the party whose output is most difficult to measure will become the residual claimant, and this assignment determines whether equity will be held by the MNE, the local owner or shared between them, and also whether MNEs will enter the host country through greenfields, brownfields or acquisitions. Hennart concludes that his model offers useful insights into the emergence of Asian multinationals.

Benito, Petersen and Welch in "Towards more realistic conceptualisations of foreign operation modes" argue that international business scholars typically treat the mode of entry decision as a comparative static analysis of the "choice process among well-specified, discrete alternatives". However, the real world is much messier. Firms appear to make much more complex and dynamic choices, regularly using a variety of mixed modes of entry, including combination of modes in "mode packages" and switching between and within both modes and mode packages. To better capture this complexity and dynamism, the authors develop the new concepts of mode dynamics, mode learning and mode inertia as key characteristics of mode packages. An abductive inferential approach, using a case study of the Finnish firm Kone's entry into the Japanese market, is used to explore these characteristics. The authors conclude that deeper longitudinal, qualitative studies, not large quantitative surveys, are needed if scholars are to develop more realistic conceptualizations of foreign operation modes.

"The end of the opportunism vs trust debate: Bounded reliability as a new envelope concept in research on MNE governance" by Verbeke and Greidanus introduces the concept of bounded reliability as an alternative to the transaction cost economics (TCE) approach to the MNE characterized by internalization theory. The authors argue that a core concept of TCE is the behavioral assumption of opportunism (self-interest seeking with guile), and that this concept should be replaced with the broader concept of bounded reliability, which can be defined as a "scarcity of effort to making good on open-ended promises", that is, why humans fail to deliver on their commitments. Bounded reliability includes two main components: opportunism as intentional deceit and benevolent preference reversal due to either reprioritization or scaling back on over commitment. Case studies of nine MNEs are used to illustrate these mechanisms within the MNE. The authors explore the implications of bounded reliability for work by international business scholars on MNE location decisions, headquarters-subsidiary relationships, and investment in firm-specific advantages.

Rangan and Sengul in "Information technology and transnational integration: Theory and evidence on the evolution of modern multinational enterprise" explore the implications of information and communication technology (ICT) on the MNE's decision to internalize transactions. On the one hand, MNEs can use ICT to reduce the transaction hazards and transaction costs of arm's length trade relative to intrafirm transactions. This should lead to more outsourcing and less in-house production by the MNE, with a consequent fall in the MNE's level of cross-border integration. On the other hand, ICT can be used to facilitate better 
monitoring and coordination of the MNE network, increasing the benefits from transnational integration. For large MNEs, the authors expect the second effect to dominate the first. The authors find support for their hypotheses using industry-level panel data for US MNEs for 1982-1997.

In "Valuation effects of global diversification", Gande, Schenzler and Senbet examine the effects of corporate international diversification (proxied by the foreign sales ratio) versus industrial diversification (proxied by the nonprimary sales ratio) on firm value for US firms over the 1994-2002 period. Their theoretical framework argues that both real and financial drivers determine the valuation effects of global corporate diversification. As the firm can choose to diversify globally or industrially or both, the authors ask how this choice affects valuation effects. The authors hypothesize that stronger host-country governance should positively moderate the relationship between firm value and global diversification. Their results suggest that both real and financial effects create value from global but not from industrial diversification. They conclude there is strong support for the unifying view that both real and financial drivers matter for global corporate diversification.

Durnev, Errunza and Molchanov in "Property rights protection, corporate transparency, and growth" draw on previous work in economics, political science and finance to analyze the impacts of corporate transparency on the efficiency of industrial investment and growth, and how these relationships are affected by the degree of property rights protection in the host country. The authors create an industry-level corporate transparency index based on four attributes: informational transparency, insider transparency, accounting transparency, and disclosure. They argue that in countries where property rights are strong, corporate transparency reduces information asymmetries, improves investment efficiencies and increases growth. Where property rights are weak, however, greater corporate transparency can backfire, leading to more government interference and higher risk of expropriation. In such situations, the firm conceals information, which creates informa-

\section{REFERENCES}

Anderson, E., \& Gatignon, H. 1986. Modes of foreign entry: A transaction cost analysis and propositions. Journal of International Business Studies, 17(3): 1-26.

Buckley, P. J., \& Casson, M. C. 1976. The future of the multinational enterprise. London: Macmillan. tion asymmetries, reduces investment efficiency and lowers growth. The authors find support for their hypotheses in a dataset for 59 industries in 69 countries for 1990-2000.

The JIBS Anniversary Issue concludes with two Perspectives. The first, by Buckley and Casson, "The internalisation theory of the multinational enterprise: A review of the progress of a research agenda after 30 years", is a major retrospective of their work on the theory of the MNE. The authors review the research agenda that began with their seminal book, The Future of the Multinational Enterprise (1976), which developed the theory of internalization as an explanation for the existence of the multinational enterprise. Although the research agenda has (not surprisingly) broadened over the years, the authors conclude that their core philosophy behind their research has not changed and that internalization theory has "retained its validity and its vitality over the past thirty years".

The second Perspective brings together short retrospectives by the winners of the 1970-1985 JIBS Decade Awards, together with a discussion of the history and significance of the Award. The authors look back at their early contributions, and assess their relevance for today's IB scholars. The topics span the IB field: adaptation vs standardization (Ward); country-of-origin (Schooler, Bilkey \& Nes); culture (Hofstede); entry mode (Goodnow \& Hansz, Davidson \& McFetridge); exporting behavior of SMEs (Simpson \& Kujawa, Bilkey, Reid); FX exposure (Giddy \& Dufey); internationalization path (Daniels, Johanson \& Vahlne); politics (Kobrin, Lecraw); and theory of the MNE (Dunning, Rugman). Here you will find early work on current topics such as institutions (Goodnow \& Hansz), SMEs and born globals (Simpson \& Kujawa, Bilkey, Reid) and negative country-of-origin effects (Schooler), and seminal pieces that have inspired the IB research agenda for decades (Dunning, Hofstede, Johanson \& Vahlne). Enjoy!

\section{NOTE}

${ }^{1}$ On JIBS as an interdisciplinary home for international business research, see the Letter from the Editorin-Chief in JIBS 39.1 and the Letter from the Editors by Cheng, Henisz, Roth and Swaminathan in JIBS 40.7.

Johanson, J., \& Vahlne, J.-E. 1977. The internationalization process of the firm - A model of knowledge development and increasing market commitments. Journal of International Business Studies, 8(1): 23-32. 